\title{
Teaching Islam in Israeli Institutions of Higher Education
}

\section{Daniella Talmon-Heller}

The idea of a workshop dedicated to the teaching of Islam was conceived by Israeli academics who teach "Introduction to Islam." This course is obligatory in all Islamic and Middle Eastern studies departments in Israeli universities and colleges, and is a popular elective course for students from various faculties. Indeed, it is a demanding mission. While teaching Islam or, for that matter, any religious tradition to those who are new to the scholarly critical approach to religion may be challenging anywhere, ${ }^{1}$ the Israeli setting poses additional difficulties. It involves teaching in classes composed of a mixed crowd of Jewish, Muslim, and Christian students, some of whom are deeply committed to their faith, while others are quite secular.

The tense climate of the Arab-Israeli conflict inevitably shapes, in one way or other, the learning environment. The uneven power relations inside Israel, often unacknowledged yet very present, as well as the prevalent stereotypes and prejudices about Islam in Israeli society and media also impact the classes and teachers. All that aside, many of the teachers who deliver this introductory course shared an urgent need to rethink and revise the "classical" syllabus, one formulated by the great founders of Islamic studies in Israel decades ago. To this end, a good number of full professors, associate professors, young instructors, and some graduate students from all of Israel's five universities, as well as from its colleges and seminaries for high-school teachers, got together for an intensive day of exchanging ideas.

The workshop was held in memory of the late Hava Lazarus-Yafeh (1930-98), a prominent scholar of medieval and modern Islam and of interfaith relations. Lazarus-Yafeh was a wonderful teacher who influenced generations of Israeli students and scholars. Eli Stern (Hebrew University of Jerusalem) delivered a moving tribute to her memory, stressing her unique qualities as a researcher, instructor, and educator and her steadfast dedica-

Daniella Talmon-Heller is a professor in the Department of Middle East Studies, Ben-Gurion University of the Negev, Beer-Sheva, Israel. This event was held at Ben-Gurion University of the Negev during April 2005. The workshop was supported by The Chaim Herzog Center for Middle East Studies and Diplomacy. The author would like to use this opportunity to repeat her thanks to Yoram Meital, Meir Bar-Asher, and all participants, and to Zipora Kasachkoff for her help in the preparation of this short paper. 
tion to promoting mutual understanding and respect among Jews, Muslims, and Christians.

The first session dealt with teaching the above-mentioned introductory course on Islam. Meir Bar-Asher (Hebrew University of Jerusalem) opened it with a lecture on the importance of comparative studies for understanding the phenomenology of religion. For teaching purposes, he recommended the inclusion of two of Lazarus-Yafeh's articles in the "Introduction to Islam" syllabus as outstanding (even if somewhat difficult for beginners) examples of the analysis of Islamic phenomena from the perspective of religious studies. The first article, "Umar b. Al-Khattab: The Paul of Islam?"” presents 'Umar's contribution to nascent Islam in a new light altogether, posing him as the "second person" of Islam. His decisive role in Islam's development is explained by comparison with Paul's figure and contribution to Christianity and that of the "second person" in other religious movements and sects. ${ }^{3}$

The second article, "The Religious Dialectics of the Hadjdj," deals with the absorption and adaptation of ancient pagan material into a monotheistic faith. Here, Lazarus-Yafeh elaborates on the difficulties that the hajj rituals pose to believing Muslims (analogous to the difficulties posed for some Christians by the Eucharist, or for some Jews by the ancient Jewish sacrifices in the Temple). Lazarus-Yafeh scrutinizes early and late sources that struggle to emphasize the hajj's Islamic character - such as the Qur'an, alGhazzali's mystical treatises, Sayyid Qutb's exegesis - and exposes the typology of their various strategies. Bar-Asher suggested that this article also be used to acquaint students with the interesting concept of condescendence (the Greek sunkatabasis), namely, the "descent" of God, or the accommodation of His demands to human weakness and deficiency.

Leah Kinberg (Tel Aviv University) called upon scholars and teachers to descend from the ivory tower and revamp a syllabus that all too often limits the study of Islam to the first 300 years of its existence. Kingurg stressed that students should be exposed to the various ways in which present-day Muslims engage with current issues and contemporary fundamental changes in religion, culture, and society. Interenet sites, both apologetic ones that seek to present a "friendly" Islam to westerners and sites operated by radical movements for the benefit of their own circles, are an excellent source of information about contemporary Islam. Moreover, since all of these sites frequently cite classical texts, they may also serve as points of departure for studying the early and medieval traditions (with proper commentary, of course) and trigger an analysis of the interplay of old and new interpretations. Demonstrating to the students how the Qur'anic Pharaoh is brought to 
life as the ideal type of present-day tyrants, how asbab al-nuzul acquire an actual twist, and how age-old polemics against Jews and Christians are applied today, make - according to Kinberg's experience - for a lively, attractive, and updated course.

Yehoshua Frenkel (Haifa University) thrashed out the obstacles instructors face when teaching about Islam to Muslim students whose worldviews are shaped by popular preachers and media images. More often than not, scientific approaches to sacred texts, namely, the Qur'an and hadith, are not only foreign to such students, but also inconceivable and even offensive to them.

Yair Schiffmann (David Yelin Seminary and Hebrew University) presented his view of the educational goal of the introductory course. For him, the transmission of reliable data, important as it is for cultivating rational views of the "Other" (that may replace, or at least modify, purely emotional attitudes), should be accompanied by a conscious attempt to raise better informed and more tolerant young citizens. He suggests that the in-depth study of such methodological and historical questions as the mutual influences of religious cultures, the similarities and differences between them, and the historical examples of fruitful cooperation between Muslims and Jews, may contribute to this process.

The second session dealt with classrom dynamics. Vardit Rispler-Hayyim (Haifa University), Aviva Schussman (Hebrew University and David Yelin College), and Michael Winter (Tel Aviv University), not to mention the session's many respondants, acknowledged the dilemmas and conflicts facing the instructor of heterogenous student bodies. However, they also recognized the advantages and possible rewards of such a diversity and multiplicity of standpoints. Of particular concern was the creation of a learning environment in which all students could feel free to express their opinions while being respectful to their fellow classmates. Many agreed that the instructor must repeatedly explain the tension between the spiritual faith-based understandings of Islam and the academic appproaches toward it, while attaching importance and relevance to both. Empathy toward those students who are exposed for the first time to scholarly treatment of their faith is required. No less important is the emphasis on the multiplicity of scholarly approaches and faith-based interpretations in all fields.

The initiation of an open talk to air out sensitive issues and the instructor's active engagement in making place for the Muslim students' special contribution were suggested. Specific ideas in this vein included asking some of them to demonstrate the prayer, recite excerpts of the Qur'an, talk about local traditions, bring cassettes of popular Qur'anic reciters and preachers to 
class, or invite the class to a neighboring mosque or some other Islamic institution were suggested. ${ }^{5}$

The third and final session focused on teaching resources, from the classical primary sources (e.g., early texts in the original Arabic and in translation) to websites and PowerPoint presentations. The overall aim was to suggest how to enrich students' experience of Islam and how to diversify teaching methods in order to incorporate current issues, recent methodologies, modern technologies, and innovative approaches. Nahem Ilan (the Lander Institute) described his successful experience of teaching a medieval Jewish Sufi text (Bahya ibn Paquda's Al-Hidayah li Fara'id al-Qulub) to a class of Jewish, Muslim, Christian, and Druze students. They all found the eleventhcentury mystical text fascinating, were able to relate to it from very personal points of view, and engaged in a fruitful dialogue with their classmates.

Muhammad al-Atawneh (Ben-Gurion University) recommended that Islamic Internet sites and informative sites about Islam be integrated into the syllabus, as repositories of original and translated Islamic texts of all sorts, as sources of information on contemporary Islamic communities and views, and as objects of study and analysis. Mindful of the unruliness of cyberspace and the dangers of misinformation, al-Atawneh suggested a list of precautions for the inexperienced surfer. ${ }^{6}$

The productive use of plastic arts, photography, and the cinema for courses on women in Islam and the Middle East was demonstrated by Ruth Roded (Hebrew University). Her PowerPoint presentation brought forth nontextual sources that shed new light on issues such as Islamic attire or the presence of women in public spaces.

The students' voice was represented in the workshop (albeit, indirectly) through a questionnaire my students had filled in at the end of the introductory course to Islam taught in the fall semester of 2005-06. While handing out the forms to the students, I stressed that they were not requested to evaluate my teaching (a standard university questionnaire is passed out at the end of every course for that purpose), but rather to assess the course itself as well as its impact upon their knowledge of Islam and their attitude toward it. They were asked to identify themselves by their religious affiliation (Jewish/ Muslim/Christian), ${ }^{7}$ degree of religious commitment (religious/traditional/ secular), ${ }^{8}$ and gender. Fifty students returned the questionnaire after having answered it fully, 10 percent of them Muslim. Obviously, the data I had collected is devoid of any statistical value, yet it may be instrumental as food for thought. The following is a summary presentation of the more significant issues that came up. 
First, I asked which topics were most interesting. Students listed (in descending order): Islam and other religions, the Shi'ah, Muhammad and the Qur'an, and the pre-Islamic Middle East. As expected, students are most interested in interfaith relations and in high-profile media issues (such as the Shi 'ahs), but - and that is less trivial - they also appreciate basic knowledge in (and beyond) the field.

Approximately one-half of the Jewish students claimed that the course had changed their attitude toward Islam, of whom some three-quarters reported that their attitude had become more positive. A few Muslim students also asserted that the course had positively influenced their attitude toward Islam. Some of the students who claimed to have been affected by the course declined to define the change as positive or negative. Regarding the atmosphere in class, most Jewish students did not feel any tension between Jews and Muslims in class, while most Muslim students felt that such tension did prevail; some of them even found it disturbing. But only a very small number of Muslim students felt that their Jewish classmates were disrespectful toward Islam. One-half of the Muslim students and most of the Jewish students reported that they had made a conscious effort not to be offensive toward members of the other religious/national group. Most students felt that the Muslim participants were given a fair chance to share their knowledge and experience of Islam with the class and that they had indeed contributed to the learning process.

The problematic aspects of the course were exposed, to my mind, in the answers of those Muslim students who admitted that they felt uncertain whether they had fully understood the difference between the perspective of the "academic" and the "believer" toward religion at the same time. Some of the Jewish students acknowledged not having comprehended the value of studying primary Islamic sources.

The most striking, though hardly surprising, finding is that in the eyes of the Muslim students a Jewish-Israeli instructor cannot teach Islam either authoritatively or properly. Most of the Jewish students who related to that issue thought otherwise. As a follow up, the majority of Muslim students reported that they would have prefered to take the introductory course with a Muslim teacher (an option that was not offered that semester), while the majority of the Jewish students reported that they had no preference in this matter. Since all students, excluding one, were unanimous in their evaluation of my teaching as evenhanded and equally respectful toward all religions, I believe that their stand has little to do with my personality or with the quality of my teaching. It is even less likely that those students were influ- 
enced by theories critical of western scholaraship on Islam - at that stage of their study they had had only minimal (if any at all) exposure to Said's Orientalism.

It is most probable that their attitude is built into the awkward situation itself and is inherent to the religious and national conflicts between Jews and Arabs in Israel. This situation raises questions that we presently could not adequately answer: What are our goals when we teach Islam to Muslim students? Should we formulate distinctive goals for distinctive groups within the same class? Would a Jewish-Muslim team, or at least a pair of instructors, best serve the needs and difficulties of our mixed classes? Your thoughts are most welcome.

\section{Endnotes}

1. For the American context, see Brannon M. Wheeler, ed., Teaching Islam (Oxford: 2003), particularly the first three chapterd, in which Wheeler, A. Kevin Reinhart, and Keith Lewinstein thoughtfully discuss various aspects of this challenge.

2. H. Lazarus-Yafeh, Some Religious Aspects of Islam (Leiden: 1981), 1-16.

3. Such as the Kaysaniyah (early eighth century $\mathrm{CE}$ ) and the Mormon Church (late nineteenth century $\mathrm{CE}$ ).

4. Lazarus-Yafeh, Religious Aspects, 17-37.

5. Each of my classes enjoyed a field trip to a mosque in the vicinity of Beer Sheva. An especially successful visit was made to a mosque in the town of Rahat, where we met with the architect who planned the (beautiful) edifice; the imam in charge of the mosque; the local representative of the Islamic Movement in Israel; and the co-ordinator of the social, educational and recreational activities conducted in the mosque.

6. For a detailed presentation of this issue, see Corrine Blake, "Incorporating Information Technology into Courses on Islamic Civilization," in Wheeler, Teaching Islam, 181-90.

7. In the Israeli context, religious and national identity are closley linked, of course. At Ben-Gurion University most (though not all) Muslim students are Bedouin Arabs, residents of the Negev Desert. The few Christian students may be Arabs from central and northern Israel, foreign students, or non-Jewish immigrants from Russia.

8. "Religious" is understood by most all Israelis, Jewish and Muslim, as observant, while traditional is regarded as not fully-practicing and yet favorably inclined toward religious tradition and customs. "Secular" is understood as non-observant but not necessarily atheistic. 